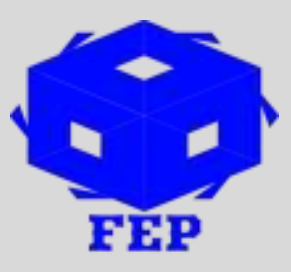

\title{
AUDITORS' INDEPENDENCE AND CORRUPTION ALLEVIATION IN THE NIGERIAN PUBLIC SERVICE
}

\author{
Ene E. Emeka ${ }^{1}$, Ene C. Josephine ${ }^{2}$
}

${ }^{1}$ Department of Accounting and Finance, Baze University, Abuja, Nigeria

*Corresponding Author: Ene E. Emeka

Corresponding Author Email: emeka.ene@bazeuniversity.edu.ng

Article Received: 09-05-19 Accepted: 30-05-19 Published: 10-06-19

Licensing Details: Author retains the right of this article. The article is distributed under the terms of the Creative Commons Attribution-Non Commercial 4.0 License (http://www.creativecommons.org/licences/by-nc/4.0/) which permits non-commercial use, reproduction and distribution of the work without further permission provided the original work is attributed as specified on the Journal open access page.

\begin{abstract}
Corruption is the greatest enemy of the Nigerian state evidenced by the recent rating of the nation as most corrupt country in the world. The debilitating effect of corruption pervades the Nigerian public service which is the machinery of government for the delivery of public goods and social services to the populace. This situation seemingly continues unabated under the watchful eyes of external auditors saddled with the responsibility of reviewing the operations of public service agencies. In evaluating the culpability of external auditors, this study investigates the external auditors' independence as a factor in combating corruption in Nigeria public service. Survey method was adopted to assess the four factors identified by the study that affect the independence posture of external auditors. The responses from the questionnaire were analyzed using the SPSS test of statistics. The result reveals that the independence status of external auditors in Nigeria is compromised in the four areas investigated: appointment, professional fees, arms-length and tenure. The study therefore recommended that external auditors should be appointed by the Nigerian supreme audit institution and their fees should be determined by the same institution to which they should also render the audit report and management letter directly.
\end{abstract}

Keywords: External Audit, Corruption, Public Service, Independence, Factors

\section{INTRODUCTION}

Every sector in Nigerian society is plagued with corruption and every Nigerian citizen has an extremely high level of corruption (Uzochukwu, 2019); "all the institutions of government in Nigeria are corrupt" (Osibanjo, 2016). These statements expose the endemic nature of corruption in Nigeria. Additionally, several instances of misstated funds, frauds and 
irregularities have consistently been reported in Nigerian government agencies making it the biggest challenge of the nation. To realize its potential and join the league of developed nations, Nigeria, being one of the emerging global economies and the largest economy in Africa must alleviate corruption and reduce it to the barest minimum. Furthermore, increase in population, changing needs of the public, advancements in information and communication technology as well as global economic changes has resulted to an increase in the demand for accountability, transparency and probity in government institutions. This demand cannot be satiated in face of the menace of corruption.

In Nigeria, Federation's auditor general is one of the key institution. The Auditor General for the Federation is required by law to report on the audited public accounts of all offices of the federation and audit all revenues accruing to the Federation from all sources. In the performance of these duties, the Office of the Auditor General directly or indirectly supervises the external audit functions of government units by appointing external auditors for the annual audit of all government offices and subsequently report to the public accounts committee of national assembly on the audit findings. The expectation of the public regarding external auditors of public institutions is that they contribute to the fight against corruption through detection and prevention of corrupt tendencies. However, despite the engagement of external auditors to examine and report on the financial operations of public institutions in Nigeria, corruption is still endemic in the public service and continues to plague the nation's economic and social health with devastating consequences of poverty, insecurity, social and economic inequality, infrastructural decays, health systems decay, among others. As corruption continues to bedevil the Nigerian state over the years, one critical area which has not been properly evaluated is the roles of auditors (both internal and external auditors) in combating the monster called corruption.

The role of auditors in the fight against corruption cannot be overemphasized as an effective and efficient system of external auditing serves as one of the vital tools for the fight. Auditors, both internal and external, serve as check against all forms of irregularities in the private and public sector organizations. However the ability of an audit to fulfill its objective is determined by the quality of the audit performed. Audit quality, according to Martin (2013), refers to a continuous process which highlights those aspects which decrease audit performance, conduct analysis, develop responses, and conduct performance monitoring and reinforcement. Audit quality refers to the ability of the auditors to detect and report material misstatements, which reflects two key determinants of audit quality: the competence and independence of the professional auditors (DeAngelo, 1981). In support of the vital effect of the independence of an auditor on audit quality, Abdul Nasser, Mustapha and Hudaib (2006) observed that in auditing profession, auditor independence is one important factor in developing mass trust. In the same vein, Enofe, Nbgame, Okunega and Ediae (2013) posited that as auditors' independence increase, the quality of the audit also improves. From the aforementioned submissions, it can be deduced that the effectiveness and efficiency of any external audit is largely dependent on the independence of the external auditors.

Auditor's independence may be defined as an auditor's unbiased metal attitude in making decisions throughout the audit and financial reporting process. Auditor's independence may be defined as an auditor's unbiased metal attitude in making decisions throughout the audit and financial reporting process. Auditor's independence may be defined as an auditor's 
unbiased metal attitude in making decisions throughout the audit and financial reporting process.

Given that, all government institutions in Nigeria apparently appoint external auditors, usually annually, to examine their books and internal control systems with the view to expressing their opinion and reporting same to the public institution's governing board and the ability to achieve this et out objective depends on audit quality, hence any influences on the independence of auditor both internal and external to the firm may impair auditors' independence and will impact negatively on audit quality. When audit quality is impaired, the objective of external audit is compromised. Therefore, if audit quality is expected to be enhanced, auditor's independence must be assured. To establish the independence of external auditors in the public service, four questions readily come to mind:

i. Does the procedure for appointment of external auditors by public institutions in Nigeria affect the external auditors' independence posture in the fight against corruption?

ii. Does the magnitude of fees received by external auditors' have any significant impact on their independent attitude towards the fight against corruption in the Nigerian public service?

iii. To what extent does the length of tenure of external audit of government institutions in Nigeria eroded auditor's independent stance in the fight against corruption?

iv. Has arms-length relationships which exist between external auditors and public institutions weakened the independence of auditors in the fight against corruption?

This research therefore intends to find answers to these questions and contribute to the existing literature in this area. The primary objective of this paper therefore is to assess factors that determine external auditors' independence and how these factors have impacted the external auditors' role in the fight against corruption in Nigerian public sector. The next section of the paper presents review of related literatures on the subject matter, while in section three of the paper, the methodology of research and the research hypothesis were discussed, the data obtained for the study were presented and analyzed in the fourth section of the paper while the last section concludes the paper and made some policy recommendations on the subject matter.

\section{REVIEW OF RELATED LITERATURE}

The concepts that underpin this study are auditors' independence and corruption. Different authors have different views on the meaning and usage of these concepts. For instance, Mautz and Sharaf (1961) proposed that practitioner's independence is based on professional independence consisted of objectivity, integrity of auditor professional. Whereas, professional independence refers to apparent independence of auditors to the public as a professional group. This view is similar to the lines of thought of American Institute of Certified Public Accountants' (AICPA) Code of Professional Conduct which defines independence as "the capacity of auditor to remain impartial and objective during the process" (AICPA Code of Professional Conduct, 2007). AICPA stated further that "it requires that the relationship between CPAs and their clients must be such that the accountants will appear independent to third parties".

These key definitions appear to be in agreement as to basic essentials of auditors' independence, summary of which is that, if their opinions on the financial statements must be 
credible, the external auditors' position should such that would enable them to be objective and impartial. On this note, Okolie (2007) equates auditors' independence, objectivity, impartiality, fairness, biasedness, and honesty". The definitions of auditors' independence above lend credence to one position which is, that auditors' independence implies objectivity and integrity, and that auditors' judgment is not subordinate to the wishes or directives of other parties such as directors or top management or his own self-interest.

Unlike the concept of auditors' independence which definitions appear to be congruent, various scholars have divergent views of the definition of corruption. Others are of the view that the concept is difficult to articulate. Dada (2014), for instance, asserted that "the nature of corruption is such that it is difficult to define and comprehend. So one definition cannot cover the entire concept". Several attempts have however been made in conceptualizing the term "corruption".

John (2013) defines "corruption as a process by which the virtue of the citizen is undermined and eventually destroyed" and he argued further "That man had been corrupted by social and political life. It is not corruption of man which destroyed the political system but the political system which corrupts and destroys man".

One very common corrupt practice in the highly rated corrupt nations is the offering of bribes to public officials to distort the truth or a legally approved procedure. Corruption involves the embezzlement of public funds for personal use, and any act that is considered to be criminal in nature according to the law of a particular society (Uzochukwu, 2019). Corruption or "corrupt" behavior refers to the breaking to the established rules for making personal gain or benefit (Sen, 1999); it is an effort by individual to use wealth thorugh illicit means and gaining at the cost of public benefit (Lipset \& Lenz, 2000)

Although there are several literature on the impact of auditors' independence on auditors' performance and the performance of organizations, literature on the impact of auditors' independence on corruption alleviation appear to be very scarce. Related research areas where several works have been done include: internal auditing and public sector governance, auditors' independence and accountability, independence of auditors general and public sector accountability, among others.

For instance, Chepkorir (2013), Yamani, (1991) and Shockley (1981) examined the factors that influence auditor's independence and accountability in different countries using different methodologies found that the role of management in the selection of external auditors is the major determinant of auditors' independence. Related researches conducted by Shockley (1981) and Mansi et al. (2005) associated longer audit tenure as likely to impair with independence (negative relationship). In contrast, Carcello and Naggy (2004), Geiger and Raghunandan (2002), Ghoosh \& Moon (2005) and Johnson et al., (2002) found positive relationship between audit tenure and auditors' independence. Nur Barizah et al (2005) supported negative association of audit tenure and auditors' independence in a Malaysian public service study. Furthermore, some researchers including Shockley, (1981); Barlett, (1993); Gul, (1989) and Teoh \& Lim, (1996) found that providing non-audit service impairs auditors' independence while others found no association, for example, Knapp (1985).

Since the Transparency Initiative survey in the year 2000 ranked Nigeria the most corrupt country out of the 90 countries which was captured in the survey, Nigeria has found itself 
struggling in the ladder of ranking of corrupt free nations. Although Nigeria has shown appreciable position over the years, the present $36^{\text {th }}$ position out of the 174 countries captured in the Transparency International survey of 2018 leaves much to be deserved in the bid to rid the country of this malaise (Transparency International, 2018).

It is obvious from the extant literature reviewed that researchers believe that auditors' independence has significant role to play in the fight against corruption. However empirical evidence on the subject matter is scarce. This present study employs empirical analysis to investigate the relationship between auditors' independence and combating corruption in Nigeria thus filling existing gap in literature.

\section{METHODOLOGY}

The research design adopted for this study is the survey design. Both descriptive and inferential statistics were adopted with the view to providing clarity of content and reaching logical conclusion. Both primary and secondary data were used. The primary data were collected using standardized questionnaires. The population of this study was the 185 existing agencies of the federal government of Nigeria as at 31st December, 2018 (Wikipedia, 2019) and the 391 audit firms (AGF Office, 2019).

A purposive sampling technique was employed to select a sample size of 50 federal government agencies and 50 audit firms. The questionnaires were administered on the Directors of Finance of the federal government agencies and the managing partners of the audit firms. The main criterion for selecting the audit firms used in the analysis is that the firm must have been auditors of at least two federal government agencies in the last 10 years. The data was analyzed using both descriptive and inferential statistics. A non-parametric method, Chi-Square (X2) was employed for the data analysis.

The following hypotheses in null form were evaluated to provide empirical evidence to the study:

$\mathrm{H}_{\mathrm{o} 1}$ : The process of appointment of external auditors in the Nigerian public service does not significantly affect their independence in the fight against corruption

$\mathrm{H}_{\mathrm{o} 2}$ : The nature of audit fees paid to external auditors does not significantly affect auditors' independence in the fight against corruption in the Nigerian public service

$\mathrm{H}_{03}$ : The tenure of auditors' engagement does not significantly affect their independence in the fight against corruption in Nigerian public institutions

$\mathrm{H}_{\mathrm{o} 4}$ : Alms-length relationship between external auditors and federal government institution does not significantly affect auditors' independence in the fight against corruption in the Nigerian public service

\section{DATA PRESENTATION, ANALYSIS AND DISCUSSION OF RESULTS}

The responses from the questionnaires administered on audit firms and Directors of Finance and Accounts of federal government ministries, departments and agencies are presented in Table 4.1 and analyzed thereafter in the adjoining sections using simple percentage and chi $^{2}$. 
From the data presentation and analyses in Table 1, it can be observed with respect to the first question, that majority of the respondents, representing about $47 \%$, believe that the amount of fees paid to external auditors may impact their independence in the fight against corruption.

Table 1

Responses From Questionnaires Distributed

\begin{tabular}{|c|c|c|c|c|c|c|c|c|c|c|c|c|c|}
\hline $\mathbf{S} / \mathbf{N}$ & STATEMENTS & 1 & 2 & 3 & 4 & 5 & Total & 1 & 2 & 3 & 4 & 5 & Total \\
\hline 1 & $\begin{array}{l}\text { Audit Fees affect External } \\
\text { Auditors' Independence }\end{array}$ & 45 & 23 & 19 & 6 & 2 & 95 & $47 \%$ & $24 \%$ & $20 \%$ & $6 \%$ & $2 \%$ & $100 \%$ \\
\hline 2 & $\begin{array}{l}\text { Audit Tenure affects Auditors } \\
\text { Independence }\end{array}$ & 71 & 13 & 9 & 1 & 1 & 95 & $75 \%$ & $14 \%$ & $9 \%$ & $1 \%$ & $1 \%$ & $100 \%$ \\
\hline 3 & $\begin{array}{l}\text { The nature of relationship } \\
\text { between Government Agencies } \\
\text { and external auditors' affect } \\
\text { independence }\end{array}$ & 63 & 17 & 8 & 3 & 4 & 95 & $66 \%$ & $18 \%$ & $8 \%$ & $3 \%$ & $4 \%$ & $100 \%$ \\
\hline 4 & $\begin{array}{l}\text { External Auditors' Should not } \\
\text { accept to audit agencies where } \\
\text { their independence may be } \\
\text { compromised }\end{array}$ & 95 & 0 & 0 & 0 & 0 & 95 & $100 \%$ & $0 \%$ & $0 \%$ & $0 \%$ & $0 \%$ & $100 \%$ \\
\hline 5 & $\begin{array}{l}\text { The process of auditors' } \\
\text { appointment in the public service } \\
\text { needs to be overhauled }\end{array}$ & 89 & 1 & 1 & 1 & 3 & 95 & $94 \%$ & $1 \%$ & $1 \%$ & $1 \%$ & $3 \%$ & $100 \%$ \\
\hline 6 & $\begin{array}{l}\text { External Auditors' tenure in the } \\
\text { public service should be one } \\
\text { year }\end{array}$ & 20 & 27 & 33 & 11 & 4 & 95 & $21 \%$ & $28 \%$ & $35 \%$ & $12 \%$ & $4 \%$ & $100 \%$ \\
\hline 7 & $\begin{array}{l}\text { After an audit year, an external } \\
\text { auditor should be reappointed } \\
\text { after ten years }\end{array}$ & 58 & 14 & 10 & 12 & 1 & 95 & $61 \%$ & $15 \%$ & $11 \%$ & $13 \%$ & $1 \%$ & $100 \%$ \\
\hline 8 & $\begin{array}{l}\text { External auditing does not } \\
\text { presently add value to the } \\
\text { Nigerian public service }\end{array}$ & 62 & 16 & 13 & 1 & 3 & 95 & $65 \%$ & $17 \%$ & $14 \%$ & $1 \%$ & $3 \%$ & $100 \%$ \\
\hline 9 & $\begin{array}{l}\text { External Auditors are not } \\
\text { independent in the fight against } \\
\text { corruption in Nigeria }\end{array}$ & 82 & 3 & 1 & 4 & 5 & 95 & $86 \%$ & $3 \%$ & $1 \%$ & $4 \%$ & $5 \%$ & $100 \%$ \\
\hline 10 & $\begin{array}{l}\text { The Nigerian audit Act requires } \\
\text { amendment }\end{array}$ & 85 & 5 & 2 & 1 & 2 & 95 & $89 \%$ & $5 \%$ & $2 \%$ & $1 \%$ & $2 \%$ & $100 \%$ \\
\hline 11 & $\begin{array}{l}\text { The Nigerian public service does } \\
\text { not recognize and appreciate the } \\
\text { role of external auditors in the } \\
\text { fight against corruption }\end{array}$ & 41 & 33 & 15 & 2 & 4 & 95 & $43 \%$ & $35 \%$ & $16 \%$ & $2 \%$ & $4 \%$ & $100 \%$ \\
\hline 12 & $\begin{array}{l}\text { External Auditors should report } \\
\text { directly to the Nigerian anti-graft } \\
\text { agencies }\end{array}$ & 85 & 1 & 3 & 1 & 5 & 95 & $89 \%$ & $1 \%$ & $3 \%$ & $1 \%$ & $5 \%$ & $100 \%$ \\
\hline 13 & $\begin{array}{l}\text { The relationship between } \\
\text { external auditors and anti-graft } \\
\text { agencies should be strengthened }\end{array}$ & 63 & 3 & 6 & 8 & 15 & 95 & $66 \%$ & $3 \%$ & $6 \%$ & $8 \%$ & $16 \%$ & $100 \%$ \\
\hline & Total & 859 & 156 & 120 & 51 & 49 & 1,235 & & & & & & \\
\hline
\end{tabular}

Source: Author's Field Work and Analysis

Also, almost all the respondents (about 94\%) are of the opinion that the procedure for the appointment of external auditors in the Nigerian public service requires urgent review if the external auditors' must contribute significantly to the fight against corruption. Mixed reaction was observed on the opinion of external auditors and Directors of Finance and Accounts on the tenure of external auditors in public service institutions. While the external auditors were neutral on the single tenure of one year for audit, public service institutions appear to favour the single tenure approach with possible reappointment after ten (10) years. Furthermore, majority of the respondents as depicted in questions 8, 9, 10 and 11 have the following views: 
external audit does not presently add value to public sector organizations; external auditors are not independent; the Nigerian Audit Act requires review and the Nigerian public service does not appreciate the role of external auditors in the fight against corruption.

Finally on the analysis of the questionnaire responses, majority of the respondents from the federal government institutions and external auditors believe that external auditors should report directly to anti-graft agencies rather than the management and board of government institutions and that the relationship between external auditors and anti-graft agencies should be strengthened.

The three hypotheses for the study were tested using $\mathrm{chi}^{2}$, the results and discussion of findings are presented in Table 2.

Table 2

Results of Data Analysis using Chi-Square

\begin{tabular}{|l|l|l|l|l|}
\hline Statistics & Aud. Appointment & Aud. Fees & Aud. Tenure & Arms-length Relationship \\
\hline Chi-Square & 60.000 & 47.571 & 60.000 & 61.857 \\
\hline Degree of Freedom & 27 & 28 & 27 & 29 \\
\hline Significance & 0.000 & 0.012 & 0.000 & 0.000 \\
\hline
\end{tabular}

Table 2 explicitly shows that all of the chi-square statistics computed are significant at the $5 \%$ level. This means that the study does not accept the four hypotheses formulated in section one. Therefore the hypotheses stated in null form are rejected and the alternate hypothesis accepted.

Specifically, the study rejects the first hypothesis which states that the process of appointment of external auditors in the Nigerian public service does not significantly affect their independence in the fight against corruption. Thus, the results of the analysis clearly show that the current procedure for the appointment of external auditors in the Nigerian federal government institutions affects the independence of the auditors in the fight against corruption. This may not be far from the reality in Nigeria as external auditors are appointed by government organizations. Federal Government Financial Regulation Sec 3210 (i) clearly provides that "the Board of each parastatal shall appoint an external auditor who shall audit and report on the affairs of the organization to the Board'. This means that the Board of government departments and agencies can hire and fire external auditors at will. The reports of the external auditors are therefore addressed to the management of the audited organizations (government organizations). This process where government institutions appoint their own auditors greatly hampers the effectiveness of external audit in the fight against corruption in Nigeria. The finding of this study in relation to the first hypothesis is consistent with the study carried out by Yamani (1991).

Similarly, the study rejected the second hypothesis which states that audit fees do not affect auditors' independence in the fight against corruption in Nigeria. Since external auditors are appointed by the ministries, departments and agencies of government in Nigeria, the remuneration of such auditors are also determined by the ministries, departments and agencies. The logical question to ask therefore is, "how can an external auditor whose remuneration is determined by the government agency he audits design his audit procedure to identify and mitigate corruption and corrupt practices?". Therefore, where auditors' fees are 
determined by the agency audited, auditors' independence may be negatively affected in the fight against corruption. This position is similar to that of Chepkorir (2013) and Zhao (2005). The study also rejects the third hypothesis which states that the tenure of auditors' engagement does not significantly affect their independence in the fight against corruption in Nigerian public institutions. It is a common fact that when external auditors become too familiar with the agencies they audit, compromise may ensue and the fight against corruption using the external auditors may be lost in such an agency. This assertion is consistent with studies conducted by Mansi et al. (2005) and Nur Barizah et al (2005). In contrast to Mansi et al. (2005) and Nur Barizah et al (2005), Carcello and Naggy (2004), Geiger and Raghunandan (2002), Shockley (1981), Ghoosh \& Moon (2005) and Johnson et al., (2002) found positive relation between audit tenure and auditors' independence.

Finally, the study rejected the fourth hypothesis which states that alms-length relationship between external auditors and federal government institution does not significantly affect auditors' independence in the fight against corruption in the Nigerian public service. Thus, arms-length relationship may affect external auditors' independence and the overall quality of external audit. In line with this argument, some researchers such as Shockley, (1981); Barlett, (1993); Gul, (1989) and Teoh \& Lim, (1996) found that providing non-audit service may bring auditors to an arms-length relationship with clients which may impairs auditors' independence.

\section{CONCLUSION AND RECOMMENDATIONS}

Corruption is endemic in the Nigerian public service and has continued to undermine the social infrastructure and economic development necessary to place the country in the league of developed nations of the world. One of the instruments for combating corruption in the public service is external auditing which must be carried out by independent professionals. Thus, all government agencies' financial operations are audited by external auditors annually yet corruption persists in the Nigerian public service. This study is an attempt to identify and examine the factors that affect external auditors' independence in the fight against corruption in the Nigerian public service. Based on the data gathered and analyzed, the study concludes that weak appointment procedure, nature of fees, tenure of assignment and arms-length relationship may adversely impact auditors' independence in their fight against corruption in Nigeria.

In line with the findings of this study, the following recommendations are proffered:

i. External auditors should be appointed by the Nigerian Supreme Audit Institution i.e. the Office of the Auditor General for the Federation;

ii. External auditors should report to the Auditor General for the Federation and the Public Accounts Committee (PAC) rather than the Board and Management of public sector organizations;

iii. The tenure of external auditors should be at most 2 years and such audit firm should not be engaged thereafter to audit the same institution until after at least 10 years from the date of the last audit exercise;

iv. The Office of the Auditor General for the Federation should strengthen its monitoring and supervision mechanisms for external auditors of public sector organizations; 
v. In line with the Financial Regulation (2009), external auditors' fees should be determined by the Auditor General for the Federation rather than the audited public sector organization;

vi. The Office of the Auditor General for the Federation should strictly monitor audit firms to ensure that relationship between external auditors and public sector organizations do not go beyond that of statutory annual audit. Thus external auditors must not perform any other financial or consultancy services for the public sector organizations they audit.

\section{References}

Adedeji, D. B., Soyinka, K. A., and Sunday, O. M. (2018). Corruption Control in the Public Sector and the Nigerian Accountant, International Journal of Academic Research in Accounting, Finance and Management Sciences, 8(1): 91-103.

Adeyemi O. (2016). 10 Biggest Corruption Cases that Shook Nigeria in 2015. Green News Publication, Nigeria.

Akinnaso, N. (2016) All the Institutions of Government are Corrupt, https://punchng.com/institutions-government-corrupt/

Animasaun, R. O. and Adegbite, I. A. (2016). Auditors' Independence and Accountability of Federal Higher Institutions in Ogun State, Reseaarch Journal of Finance and Accounting, 7(24): 188-2013.

Bartlett, R.W. (1993). A scale of perceived independence: New evidence on an old concept, Accounting, Auditing \& Accountability Journal, 6(2), 52-67.

Carcello, J.V. and Nagy, A.L. (2004). Audit firm tenure and fraudulent financial reporting, Auditing: A Journal of Practice \& Theory, 23(2), 55-69.

Chepkorir. C., (2013). Factors Influencing Auditor's Independence and Account-ability, A Case Study of KTDA Affiliated Tea Factories In BOMET and KERICHO County, KENYA. a research project submitted to school of business and economics in partial fulfillment for the award of degree in business management (accounting option) maasai mara university.

Danladi, (2007). Nigeria Ranks 148 on the 2007 Corruption Perception Index. Naira Land Publication, Nigeria.

DeAngelo, L. E. (1981a). Auditor size and audit quality. Journal of Accounting and Economics, 3(1), 183-199

Dr A. O. Enofe Dr C. Nbgame Okunega, E. C Ediae, O. O,2013. Audit Quality and Auditors Independence in Nigeria: An Empirical Evaluation, Research Journal of Finance and Accounting, 4(11)

Financial Regulations (2009). Federal Republic of Nigeria Official Gazette, No. 72.

Geiger, M.A. and Rama, D.V. (2003). Audit fees, nonaudit fees and auditor reporting on stressed companies. Auditing: A Journal of Practice \& Theory, 22 (2), 53-69.

Ghosh, A. and Moon, D. (2005). Audit tenure and perceptions of audit quality, The Accounting Review, 80 (2), . 585-612

Gul, F.A. (1989). Bankers' perceptions of factors affecting auditor independence, Accounting, Auditing \& Accountability Journal, 2 (3), 40-51 
Johnson, V.E., Khurana, I.K. \& Reynolds, J.K. (2002). Audit-firm tenure and the quality of financial reports, Contemporary Accounting Research, 19(4), 637-660.

Jola Sotubo (2016). Senators make N15M monthly, Reps 10M,' Ex-president says. Pulse Nigeria News Publication, Nigeria.

Khan, M. A. (2006). Role of audit in fighting corruption. In Ethics, Integrity, and Accountability. In the Public Sector: Re-building Public Trust in Government through the Implementation of the UN Convention against Corruption. Russia: Ad Hoc Group Meeting On.

Knapp, M.C. (1985). Audit conflict: An empirical study of perceived ability to resist management pressure, The Accounting Review, LX (2), pp. 202-211.

Liu, J., \& Lin, B. (2012). Government auditing and corruption control: Evidence from China's provincial panel data. China Journal of Accounting Research, 5(2), 163-186. https://doi.org/10.1016/j.cjar.2012.01.002

Mansi, S.A., Maxwell, W.F. and Miller, D.P. (2004). Does auditor quality and tenure matters to investors? Evidence from bond market. Journal of Accounting Research, 42 (4), $755-793$

Morris, S.D. (1991). Corruption and Politics in Contemporary Mexico. University of Alabama Press, Tuscaloosa.

Nur Barizah Abu Bakar, Abdul Rahim Abdul Rahman and Hafiz Majdi Abdul Rashid. (2005). Factors influencing auditor independence: Malaysian loan officers' perceptions, Managerial Auditing Journal, 20(8), 804-822.

Nwakanma, O. (2018) The Auditor-General's Report, https:// www.vanguardngr.com/2018/08/the-auditor- generals-report/

Ogunyemi, A. O. (2014) Auditing and Corruption in Nigeria: A Review of the Legal Weight of the Audit ACt of 1956, Historical Research Letter, 15, 1-7.

Okoye, R. (2012) Nigeria Has Lost $\$ 400$ billion Oil Revenue to Corruption Since Independence. The Daily Post, extracted from: https: // dailypost.ng /2012/08/31/nigeria-lost-400bn-oil-revenue-corruption-since- independenceezekwesili/

Oluyede, P.A. (1988), Nigerian Administrative Law. Ibadan: University Press Plc.

Otalor, J. I. and Eiya, O. (2013) Combating Corruption in Nigeria: The Role of the Public Sector Auditor, Research Journal of Finance and Accounting, 4(4): 122-131.

Shockley, R.A. (1981). Perception of auditors' independence: An empirical analysis, The Accounting Review, LV1(4), pp. 785-800

Teoh, Y.H. and Lim, C.C. (1996). An empirical study on the effects of audit committees, disclosures of non-audit fees, and other issues on audit independence: Malaysian Evidence, Journal of International Accounting, Auditing \& Taxation, 5(2), 231-248.

Transparency International (2018), Returning Nigerians' Stolen Millions, Transparency International publication.

Uzochukwu, M. (2019). Corruption in Nigeria: Review, Causes, Effects, and Solutions, https://soapboxie.com/world-politics/Corruption-in-Nigeria.

Uzochukwu, M. O. (2013). Challenges in Nigeria and Solutions on how to resolve them, published by Hubpages Inc., California, United States. 
Wale, O. (2018). APC vs PDP: Atiku lambasts Buhari again, mocks fight against Corruption [Full text], published by Daily Post, Nigeria.

Webby (2018), Abacha loot: Osinbajo speaks on return of $\$ 322 m$ by Swiss govt, Online News report.

World Bank Group (2013). Poverty and Equity, World Bank documentation.

Yamani, A., (1991). The factors that affect on external auditor independency from point of views the analysts and borrowers in the Saudi Arabia, General management Journal, Al Riyadh, (71), pp. 183-229. 